\title{
8: 6722860-6715525
}

National Cancer Institute

\section{Source}

National Cancer Institute. 8: 6722860-6715525. NCI Thesaurus. Code C42127.

Physical location of DEFB1_Gene 